\title{
Globalization and International Management: In Search of an Interdisciplinary Approach
}

\author{
Ana Lucia Guedes* \\ E-mail address: guedes@fgv.br \\ Escola Brasileira de Administração Pública e de Empresas da Fundação Getúlio Vargas \\ Rio de Janeiro, RJ, Brasil \\ Alexandre Faria \\ E-mail address: afaria@fgv.br \\ Escola Brasileira de Administração Pública e de Empresas da Fundação Getúlio Vargas \\ Rio de Janeiro, RJ, Brasil
}

\begin{abstract}
This paper, based on the international relations and international political economy literature, shows that the international management field has been influenced by certain national interests, particularly from the United States, and also that it reproduces a particular theory of globalization that benefits the interests of transnational corporations. One of the most concerning outcomes of this dominant perspective is the suppression of governance issues 'managed' by these corporations and the interests of other key agents, such as governments. The interdisciplinary approach outlined in this paper challenges the hegemonic influence of the globalist theory within the international management field. The approach proposed addresses the domains of management and governance by recognizing from a multidimensional perspective on globalization, the political and economic interfaces between public and private, and more specifically, between government and transnational corporations. This could make the knowledge produced by the field relevant not only to transnational corporations but also to local governments, local managers, public administrators and policy makers in developing countries.
\end{abstract}

Key words: international management; globalization; management and governance.

Received 16 December 2005; received in revised form 04 December 2006.

Copyright (C) 2007 Brazilian Administration Review. All rights reserved, including rights for translation. Parts of this work may be quoted without prior knowledge on the condition that the source is identified. 


\section{INTRODUCTION}

Globalization was depicted in the early 1990s as the ultimate stage of development for the field of international management. Globalization would require from large business firms highly skilled managers to cope with the challenges and responsibilities of the so-called global market. Ten years later, the scenario has changed considerably. As globalization headed towards placing an extraordinary amount of power in the hands of large corporations, international management became a major concern not only to business firms and their managers, but also to governments and other institutions (Boddewyn, Toyne, \& Martínez, 2004).

The Enron affair, among other recent corporate scandals, challenged the grounds of so-called global capitalism (Soros, 1998) and brought about a lack of confidence in large corporations in global terms (Child, 2002; Clark \& Demirag, 2002). In spite of the importance of these transformations and events, the international management (IM) literature - led by the United States (US) - fails to address the increasing power of transnational corporations (TNCs) and the corresponding implications for managers and other social constituents.

This problem is particularly important in developing countries and has been pointed out by a key US scholar as a major challenge to the IM field.

Growing concerns over the proclivity of MNCs in the late 1990s to expand acquisition instead of by greenfield investments, concerns over the physical environment and sustainable development, the increasing awareness of MNC managers of the importance of 'non-market strategy' (which often translates into building systematic influence over policy-making), and a growing interest among sociologists in the effects of MNCs on class structure and political systems in developing nations all suggest that MNC managers will face increasing challenges in the next decade. (Westney, 2005, p. 164).

The authors of this article understand that in order to fill this gap researchers in the IM field should address not only issues at the level of 'management' itself but also at the level of governance. Management is a "historically and socially constructed institution" (Boddewyn et al., 2004, p. 205) and this explains why problems and situations at the international level may be interpreted differently by different agents or 'managers'. This explains why some academics challenge the universal approach to 'management' construed in the US and its subsequent automatic conversion into 'international management' (Boddewyn, 1999; Martinez \& Toyne, 2000). As a consequence, this article states that researchers should challenge the US dominance in the field and foster interdisciplinary developments with international political economy (IPE), as a sub-domain of international relations (IR), in order to take seriously the argument that "IM is, or should be, the most eclectic of all” fields (Contractor, 2000, p. 7).

Why IR? One of the main reasons is that IR has historically focused on international issues led by states and governments (Halliday, 1999). A second reason is that, more recently, IR researchers following an IPE perspective (e.g., Strange, 1994) paid special attention, from a governance standpoint, to the increasing power of TNCs and their interactions and relations with states and governments in developing countries.

This article shows that the IM field has been developed from a dominant perspective that favors certain interests of TNCs. One of the most concerning outcomes of this perspective is the suppression of governance issues 'managed' by TNCs and also the interests and voices of other key agents, such as the government. Accordingly, by fostering the development of an interdisciplinary framework with the field of IPE, researchers could improve the relevance of the IM field, especially in developing countries.

The excessive focus of IM researchers on 'managerial' issues ${ }^{(1)}$ and the neglect of governance issues have to do with the dominance of an extremely pro business theory of globalization within the field, 
especially in the US. The main objective of this article is to show that interdisciplinary developments between the fields of IM and IPE are necessary, especially from the standpoint of developing countries, for the construction of a more contemporaneous perspective in the field of $\mathrm{IM}^{(2)}$.

In spite of the difficulties one faces to define management and governance - which to some extent have to do with the difficulties IR and IPE scholars have to define state and nation (Halliday, 1999), to differentiate politics and economics (Strange, 1994) or even to differentiate between management and government in the context of globalization (Mintzberg, 1996) - the authors of this article point out the main difference: management is more closely related to practices and powers of managers of business firms; governance is more closely related to practices and powers of higher-order actors and networks which both constrain and enable the practices and powers of managers of firms ${ }^{(3)}$.

Accordingly, governance is addressed in this article as "the totality of institutional arrangements including rules and rule-making agents - that regulate transactions inside and across the boundaries of an economic system" (Hollingsworth, Schimitter, \& Streeck., 1994, p. 8). This is particularly important in the context of globalization as a result of the increasing imbalance between 'management' and 'government'. "Because capitalism has supposedly triumphed, the private sector became good, the public sector bad, ... If we are to manage government properly, them we must learn to govern management.” (Mintzberg, 1996, p.76)

Drawing upon the IPE literature the authors of this article point out that a governance standpoint in IM should focus on political and economic strategies and practices (Strange, 1994, 1996; Stopford \& Strange, 1991) of transnational institutions, governmental authorities, top executives and stockholders of transnational corporations, non-governmental organizations, local institutions and also on the networks (Sklair, 1995) formed by these powerful actors.

This article is divided into four sections. In this first section the authors present a brief introduction to the main objectives of the article. In the second section the authors describe the dominant approach in the IM literature and show, grounded on IR, IPE and Sociology literatures, that it represents certain interests of TNCs by reproducing a particular theory of globalization. In the third section the authors argue that IM researchers, especially in developing countries, should embrace an interdisciplinary approach to globalization, which problematizes and places special emphasis on the interfaces between the public and the private domains. Finally, the authors present concluding considerations and implications of the development of an interdisciplinary framework to address issues at both management and governance levels.

\section{INTERNATIONAL MANAGEMENT AND GOVERNANCE ISSUES}

This section is divided into two parts. In the first part, the importance of fostering interdisciplinary developments in the field in order to challenge the US hegemony in the literature is stressed. In the second part, how national the field has become through the analysis of its constitution in the US is shown in addition to the influence of TNCs on its expansion throughout the 1990s.

\section{Hegemony and Interdisciplinarity in IM}

From the early 1990s globalization demanded a large amount of efforts, skills and resources - from private and public organizations in developed and developing countries - to enable managers, executives, public officers and researchers to deal with a new reality and corresponding challenges. Even though the traditional definition of international management - namely, management crossing borders - represents only the interests and needs of big business firms and their managers, we agree with the argument that 'international management' actually applies to a broad spectrum of "organizing projects around the world” (Boddewyn et al., 2004, p. 196). 
The IM field, led by US scholars (see Parker, 1997), has been pushed by those new demands, but has failed to address the 'big picture'. The field placed excessive emphasis on private interests and actors and as a result marginalized fields historically related to the public domain, such as IR and IPE, in addition to certain approaches within international business (see Buckley, 2005).

The most influential authors in IM argued in the early 1990s that globalization was a new reality that would force business firms, citizens and policy makers to see the world as a growing interdependent network (see Ohmae, 1989b; Parker, 1997). In those texts, such a network was portrayed as 'naturally' led by big business firms, especially from developed countries, and their 'international managers'. For most authors in the US, globalization meant the fall of the national boundaries that impeded the full development of the private sector and the corresponding creation of economic opportunities and development (Ohmae, 1989b). Most IM and international business (IB) scholars in the US shared the assumption that, with the end of the Cold War in 1989, 'certain' Western values (e.g. universalism, transparency, and liberal democracy) as well as economic and political institutions would prevail because "the rest of the world will acquiesce to their superiority" (see Boddewyn et al., 2004, p. 202). As such, the decay of the public domain beginning in the early 1990s should not be regarded as a problem but as a 'global asset' (Ohmae, 1990).

This representation of a 'new reality' is drawn from two main discourses. The first is that global economic integration increases exchanges and leads to global growth, in accordance with the ideologies of 'free market' and 'free trade' (see Steffek, 2003). The second is that historical processes of disintegration and political stratification have been caused by ineffective states and political ideologies. Key IM authors understand that globalization is the ultimate victory of the economic against the political and, correspondingly, of the private over the public. Globalization is portrayed as an economic force of political liberation that releases mechanisms of oppression and provides opportunities (Ohmae, 1990, p. 35).

From the particular standpoint of those authors, globalization means unlimited competition, access to markets and progress for all - as a result of the fall of boundaries between nations, cultures and organizations and also between the public and the private. Such an underlying theory of globalization rationale suppresses governance matters related to supranational institutions, international regulations and international law (Contractor, 2000). This is a key issue that differentiates IM from IB and places greater importance on the former. Besides optimization in cross-cultural management and teams, researchers state that globalization demands and allows the formation of an increasing number and more types of "partnerships among organizations" (Parker, 1997, p. 425; Ohmae, 1989b). Accordingly, they assume that partnerships between large corporations and local governments are equally beneficial for all (see Bartlett \& Ghoshal, 1989; Doz, 1986). More specifically, they state that those networks are more effective than industrial policies ruled by government (Larry, 1994).

These powerful discourses are based on the idea that structures and organizations based on economic interdependence, the free market and management replace 'old' and ineffective structures and organizations grounded on politics, coercive government and poor public administration. A key problem is that many researchers from other areas have demonstrated that imperialism is a more realistic meaning of globalization (see Banerjee \& Linstead, 2001). More specifically, different authors argue that TNCs and transnational institutions became hegemonic players and that during the 1990s the exercise of such extraordinary power - illustrated by recent corporate scandals - made some of the contradictions of global capitalism obvious (Korten, 2001; Soros, 1998).

The question is: why have IM researchers overlooked these important issues? One of the reasons is that, as result of its infant status (even marginal in the early 1990s) within the US business academy, the IM field has had to fight for its constitution and legitimization as an autonomous discipline ${ }^{(4)}$.

Before the 1990s, there had hardly been an article on the international dimension of management in the canonical outlets of Academy of Management Journal and Academy of Management Review. Suddenly, starting in the late 1980s, converts to internationalization flocked into the church in large numbers. It seemed that everyone, from secretaries of education to deans to ordinary faculty, 
discovered the need to internationalise the business curriculum and management research (Contractor, 2000, p. 3).

IM researchers then had to develop knowledge that could resolve managerial problems chosen by TNCs (Contractor, 2000). They also had to set the boundaries of the field by competing with the more traditional functional areas of management - such as marketing, human resources, and accounting - for attention and research funds, most of them from TNCs. This battle within the business academy helped prevent IM researchers from addressing governance matters.

The struggle between the IM field and the functional areas of management within the business academy and the subordination of that field to certain interests of TNCs may explain why three key questions emerged in the late 1990s: (a) what is international management?; (b) who defines the scope of international management?, and (c) which fields of knowledge constitute the IM field? (see Boddewyn, 1999; Boddewyn et al., 2004; Martínez \& Toyne, 2000). These recent questions are of central importance to the development of the field from an interdisciplinary perspective.

Parochialism and ethnocentrism may also explain why the field has overlooked governance issues that are so important in and for developing countries. Different authors have pointed out that US business researchers have developed theories and research without being sufficiently aware of non-US contexts, models, research and values (Boyacigiller \&Adler, 1991, p. 262).

This would not be viewed as so surprising by IR researchers nor by those who point out colonialism as a key issue behind the processes of the constitution of academic fields, including the field of management (Banerjee \& Linstead, 2001; Clegg, Ibarra-Colado, \& Bueno-Rodriguez, 1999). Researchers argue that globalization reproduces historical processes of imposition and the dissemination of certain "cultural patterns, values and ideas" (Held, McGrew, Goldblatt, \& Perraton, 1999, p. 336) at the expense of others. Correspondingly, globalization leads to the suppression of local cultural patterns, values and ideas. They also argue that TNCs play a key role in this asymmetric scenario of imposition and diffusion of certain 'ideas'. This explains why the media industry, dominated by TNCs within the context of globalization, has become one of the most important topics for more critical IPE scholars (Dicken, 1998; Strange, 1996). This also explains the increasing influence of TNCs in business schools and universities (Sklair, 2001) in different parts of the world.

Given this scenario of high-order influences and interests, the IM field in developing countries or regions requires a critical appraisal of the dominant knowledge produced in more developed countries, especially the US. IM should not be treated as 'neutral' or 'non-national'. Accordingly, it should not be addressed from a mere 'managerial' perspective. Such a narrow (or ideological) standpoint has been beneficial to certain interests of TNCs, at the expense of the legitimate interests of other 'players'.

Dependency theory (see Table 1), an important theoretical stream developed in the 1970s in the IR field, is of help to the undertaking of such an endeavor. This theory, which has been ignored by the IM dominant literature, was rediscovered recently by researchers who were in pursuit of a more comprehensive and contemporaneous understanding of globalization (see Hettne, 1995). Dependence theory ${ }^{(5)}$ was at its peak in the 1970s but faced serious decay in the 1980s in developing countries when the so-called Asian Tigers (South Korea, Taiwan, Singapore and Hong Kong) experienced a period of intense and rapid economic growth. This was read by many analysts in the 1980s as a sign of the arrival of a 'new capitalism'. However, as demonstrated by IR researchers in the 1990s, their sudden integration into the worldwide market took place as the governments of leading countries (Ronald Reagan and Margaret Thatcher, in the US and United Kingdom respectively) promoted liberal policies that "stressed the role of the market forces and the minimization of the state bureaucracy and regulation” (Jackson \& Sorensen, 1999, p. 201). 
Table 1: Dependency Theory of Underdevelopment

\begin{tabular}{|l|}
\hline \multicolumn{1}{|c|}{ Key Assumptions } \\
\hline $\begin{array}{l}\text { Underdevelopment is caused by factors external to the poor countries. Foreign interests originated in } \\
\text { the developed West dominate Third World countries. }\end{array}$ \\
\hline $\begin{array}{l}\text { Underdevelopment is not a phase of 'traditional society' experienced by all countries. Both } \\
\text { development and underdevelopment are results of a single process of global capitalist development. }\end{array}$ \\
\hline $\begin{array}{l}\text { Underdevelopment is due to external, primarily economic, forces; these forces result in crippled and } \\
\text { distorted societal structures inside Third World countries. }\end{array}$ \\
\hline To overcome underdevelopment, a delinking from external dominance is required. \\
Source: Jackson and Sorensen, 1999, p. 201.
\end{tabular}

A key argument of contemporary researchers who draw upon the dependency theory for the understanding of globalization is that TNCs bring benefits for development in less developed countries only under certain political and economic conditions. In states that are weak and have underdeveloped local counties, TNCs dominate the host country, becoming monopolists in their industries without contributing to local development. In countries in which the state is weak, TNCs define in one way or another important governmental policies, such as the tax policy, currency emissions, trade and monetary systems, welfare policies, ecological issues and labor unions (Chang \& Ha, 2001, p. 33). Only in states that are strong and have a well-developed local economy could TNCs bring some degree of development or progress to the host country (Sorensen, 1983; Sklair, 2001).

In spite of debates on the robustness of the principles of dependency theory and on the difficulties in keeping the representation of the multinationals as "agents of American imperialism [rather than] as potential allies" within the context of globalization (Strange, 1992, p. 5) what must be pointed out here is that TNCs and the dominant knowledge in IM should not be taken, especially in emerging countries, as capable of fulfilling the requirement of 'political neutrality'.

In Brazil, one of the most visible and controversial outcomes of the asymmetries between TNCs and local government ${ }^{(6)}$ is the predatory tax wars that have been played by local councils (municipalities such as São José dos Pinhais-PR, Porto Alegre-RS, Salvador-BA andJuiz de Fora-MG) for foreign direct investments in the automotive industry (see Arbix, 2000; Humphrey, 2000). Correspondingly, the authors of this article understand that interdisciplinary developments and the recognition of governance issues could contribute towards increasing the expected relevance of the IM field in developing countries (see Rocha, 2002).

\section{A Historical Understanding of the National-International Issues in IM}

A more comprehensive understanding of these questions demands a critical and interdisciplinary analysis of the national-international dichotomy that lies behind the historical processes of constitution and legitimization of the IM field in the US academic setting and its subsequent export to other countries (Boddewyn et al., 2004) from this perspective. Researchers should focus on two critical questions: (a) who should define what international management is?, and (b) should there be a universal definition of international management which is applicable to any country?. These critical questions challenge the agreement on the non-neutrality of academic knowledge in management (Caldas \& Wood Jr., 1997; Clegg et al., 1999).

One may argue that the IM field has a particular meaning and relevance by opposing the notion of 'national management'. In other words, the IM field exists because it addresses those issues that could 
not be addressed by a field that might be called 'national management'. It is worth noting that the term 'national management' does not exist in the US academic setting (as a result of the US dominance in management such a term does not exist in other countries). Even though it is widely recognized that 'management' as we know it is a set of practices and knowledge 'made in US' (Locke, 1996), 'national understand it is taken as 'universal management' in the US. This helps explain the difficulties that researchers in the US face to develop knowledge in the field from a less parochial or ethnocentric standpoint (Boyacigiller \& Adler, 1991).

This important feature calls into question not only the legitimacy of the massive international diffusion of the management knowledge produced by US academics (Baruch, 2001; Parker, 1997), but also the constitution of the IM field. Some authors argue that the universal character of management was construed in the US because it was necessary for the legitimisation of the discipline within the university setting. Other authors have demonstrated that the universal feature of management was driven by colonialist interests of US corporations and government (Kedia, 2006; Locke, 1996; R. Mir, A. Mir, \& Srinivas, 2004; Tragtemberg, 1980).

Another issue explains the national feature of management in the US. When the field of management was built in the US, other fields of academic knowledge already established treated it as a second-class field. For fields of knowledge such as Sociology, Law, Economics and Political Science, the management of private firms should be 'governed' by national interests, structures and institutions (Gilpin, 2001). From this perspective, management issues and interests were subordinated to governance issues at the nation level. Accordingly, it was not necessary to take 'management' - which was ideological or conveniently taken and portrayed as 'universal' at the time - as 'national management'. At the time, this issue was not viewed as being particularly problematic because no one, even in the US, could foresee that the field of management would become as important and influential as it has become over the last fifty years.

A similar process marked the constitution and legitimization of the IR field in the US context. The field faced serious obstacles within the academic setting in the early stages because academics of other fields rejected the idea that important issues, interests, decisions and institutions at the national level could be 'governed' by (or subordinated to) issues, interests, decisions and institutions at the international level (Halliday, 1994; 2001). Together these arguments help explain why most of the literature produced in the US reproduces 'national' interests and why researchers from developing countries or regions should approach the IM field from a critical standpoint.

More recent research on globalization challenged the 'global' feature of TNCs and the "myth of the powerless state" (Held \& McGrew, 2000; Weiss, 1998) by pointing out the relationship between TNCs and national governments. “....since the mid 1980s, the general complexion of the interface between national governments and TNCs has shifted from being predominantly adversarial and confrontational to being no-adversarial and cooperative” (Dunning, 1998, p. 281).

IR researchers demonstrated that one of the key features of globalization is that TNCs have gained the status of states in economic and political terms. The dominant IM literature has largely ignored the political implications of this new status since it could raise the recognition that TNCs have become a serious threat to national sovereignty in several countries. Conversely, such an asymmetrical picture, in terms of political and economic power of corporations in relation to local governments, especially in developing countries, became a key issue to the IR field in the 1990s (Dicken, 1998; Jackson \& Sorensen, 1999; Strange, 1996).

Sociology authors have pointed out that one of the main objectives of globalization is to transform nationalism - a term legitimately used in the 1970s and 1980s as "a political and cultural project which seeks to achieve self-determination and to create and shape states” (Held et al., 1999, p. 336) into 'patriotism' (Pinzani, 2002) or 'protectionism' (Sklair, 2001). This twist of meanings has been beneficial to TNCs and helps explain why the dominant IM literature overlooked governance matters (Bartlett \& Ghoshal, 1989; Ohmae, 1990). 
The national character of the IM literature produced in the US has been pointed out by different authors (Boddewyn, 1999; Martínez \& Toyne, 2000). The most important 'national' battle has been played by North Americans and Europeans, without any reference to developing countries. Some key authors argue that US business firms are more capable of understanding and practicing international management and business than the Europeans. The main argument is that the US was responsible for the construction of the so-called "managerial capitalism" (Chandler, 1962), the capitalism governed by managers and big companies which was exported to other countries as a universal governance structure. This 'made in the US' capitalism was of great importance in the $20^{\text {th }}$ century (see Gilpin, 2001) because it challenged authoritarian practices and asymmetric governance structures which are portrayed as being typically 'European ones’ by key IM authors (Bartlett \& Ghoshal, 1989, p. 43).

The legacy of managerial capitalism helps explain why key IM authors assume that managers and the big corporation are legitimate actors and resources for economic development and social welfare. This approach suppresses the political feature of controversial strategies and practices implemented by US corporations in recent decades, both domestically and abroad (Clark \& Demirag, 2002; Jenkins, 1987; Mokhiber \& Weissman, 1999).

In spite of the historical and contemporaneous disputes between the US and Europe, this 'managerial' ideology was also convenient for many European TNCs because it suppressed colonialist practices implemented by European countries (Said, 1979). Given this complicated scenario of interests and ideologies it is not unsurprising that the growing IM literature has embraced a managerial perspective (see Acedo \& Casillas, 2005), at the expense of governance matters.

IM gained the interest and support of a large mass of managers, in different countries, as the literature emphasized the differences among managers from distinct nationalities in large international business firms from a cross-cultural standpoint (Hofstede, 1980). This emphasis on inter-cultural issues (Hampden-Turner \& Trompenaars, 1993; Jackson, 1995; Usunier, 1998) was aimed at transforming differences and cultural diversity into positive factors for the global expansion of corporations and, correspondingly, the promotion of economic development in a large number of host countries and regions.

International issues at the level of governance, such as those related to the political and economic dimensions of the performance of TNCs in developing countries, have been overlooked. Consequently, the argument that one of the main features of globalization is the enlargement of the asymmetries between developing and developed countries or regions was suppressed (Furtado, 1999; Jackson \& Sorensen, 1999; Sklair, 1995; 2002; Wallerstein, 2005).

More recently, some researchers based in the UK, put forward a particularly critical approach on IM. They point out that the main problem is not the ethnocentric and colonialist features of the literature. The key issue is that IM has been transformed into a new market opportunity for business schools in developed countries. In other words, it is argued that the field of IM became a sort of new market frontier within the business academy (see Kedia, 2006). In financial terms, IM has become highly important for business schools because it attracts students from different nationalities, pushes the internationalization of these schools, and enables them to access research grants and other resources from TNCs. Such a market-oriented strategy of business schools puts Europeans and the US into the 'same boat' and also helps to explain why the IM field has overlooked the political feature of globalization (Case \& Selvester, 2000, p. 12).

David Boje, a critical researcher based in the US, argues that in parallel to the spread of globalization, TNCs have colonized business schools and even universities (Boje, 2000, 2001). This helps explain why IM textbooks, used in an increasing number of countries and regions, treat corporate reports produced by TNCs as 'truth' rather than 'corporate propaganda' (see Sklair, 1995; 2001). In these texts, Nike presents itself as an agent for ecologic and economic development; Monsanto as an organization committed to the cure of world famine; the World Bank as an institution concerned with the elimination of diseases through the financing of education programs, and the 
World Trade Organization as an institution focused on eliminating world poverty (Boje, 1999; Klein, 1999).

This is similar to the way corruption and bribery issues have been addressed in the IM literature. Bribery of foreign officials by US companies and accounting tricks to disguise it (Kaikati \& Label, 1980) are portrayed as necessary resources for TNC executives because of the low moral standards of public administration in developing countries (Czinkota, Rivoli, \& Ronkainen, 1992, p. 185).

What is even more concerning is that the IM literature has reached areas of knowledge related to the public/political dimension such as economic development, public administration and public policy (Klijn \& Koppenjan, 2000; Porter, 2000). This sort of uncritical transfer of private (management) solutions to the public realm (Mintzberg, 1996) involves political ideological and governance matters - illustrated by the Enron case - that should not be overlooked by the IM literature, especially in developing countries.

It deserves to be mentioned that the White House legitimized overtly the 'corporatization' of the state in the mid 1990s - and, in consequence, most of the IM dominant literature - when former US president Bill Clinton stated in the era of globalization that "each nation acts as a big corporation competing in the global market” (Krugman, 2001, p. 4). The next section shows how the IM literature reproduces a particular theory of globalization, grounded on the retreat of the national state and on the increasing power of TNCs.

\section{UNDERSTANDING GLOBALIZATION}

This section, grounded on a critical review of the globalization literature, has been divided into three parts. The first describes and explains two extreme theoretical approaches on globalization. The second presents a more comprehensive approach of globalization. In the end, as the conclusion of this article, the authors address key issues for the development of an interdisciplinary approach that recognizes the governance level of IM.

\section{The Major Debate in the Globalization Literature}

Held and McGrew (2000, p. 7) argue that the term 'globalization' has only actually been used since the early 1970s. At that time, the most known theoretical approaches assumed the separation of internal and external issues, more specifically the national and the international domains. Political and economic interdependence was then explained mainly by rival theories such as the world system theory (Wallerstein, 1974) and the complex interdependence theory (Keohane \& Nye, 1977). More recently, after the fall of the so-called state socialism and the establishment of capitalism at a global level, globalization has been transformed into a key concept within the academy and within diverse domains of public and private life, in almost every corner of the world (see Held, 2000; Keohane \& Nye, 1998; Wallerstein, 2000, 2005).

Interestingly, Held and McGrew (2000) point out that a key feature of globalization is that everybody argues that it exists but few, if any, are capable of defining what it is. They argue that there is not a single and universally accepted definition of globalization (see also Thompson, 2000). In spite of this scenario of conceptual disputes, most of the IM literature reproduces a particular theory of globalization. More specifically, most authors in the field of IM reproduce, whether consciously or not, an extreme theoretical pro globalization approach (Clark \& Knowles, 2003, made a similar argument regarding the IB literature).

The understanding of the globalization phenomenon by IM researchers has been constrained by the intense diffusion of two extreme theoretical approaches. These approaches, which dominate the academic literature and the media in general, have blocked the dissemination of other theoretical 
approaches that could enable the development of an interdisciplinary literature in the IM field which takes into consideration governance issues in developing countries or regions. The globalization debate has been led (Held \& McGrew, 2000; Hirst \& Thompson, 1998) by two major theoretical groups or factions: (a) those who see globalization as a historical and real process - the so-called 'globalists', and (b) those who see globalization as a mythical or ideological construction - the socalled skeptics.

The skeptics argue that globalization is a myth that legitimizes a worldwide neo-liberal project, whose major conceptual or ideological basis is the Washington Consensus ${ }^{(7)}$. Grounded on this understanding, the skeptics argue that the 'global' cannot be empirically investigated; for this reason, globalization has no descriptive or explanative value. They report that the literature shows analyses based on abstract and imprecise models of the global economy, global culture and global society. Consequently, the skeptics argue that the concepts of internationalization, regionalization or ‘triadization’ are more valid than globalization (Held \& McGrew, 2000, p.14-17).

From the standpoint of IM researchers, the skeptical perspective is problematic because it places excessive importance on national and 'inter-national' boundaries. This could lead to the recognition of imperial or colonial issues - regarding the corresponding political, economic, social and legal domains - in the globalization era. Its focus on national boundaries disclaims the dominant representation of the global market as a sort of 'free market' governed by 'free enterprises'. The skeptics' point of view emphasizes political questions more closely related to the public and government domains rather than economic questions more closely related to the private domain. Moreover, this approach is not convenient for TNCs since 'nationalists' have used it to describe or explain anti-globalization and antiTNC movements. In other words, this theoretical perspective challenges the major interests of TNCs.

At the other extreme of the theoretical debate, the globalists take the hegemonic side. They deny the argument that globalization is an ideological construction or synonymous with imperialism or colonialism. They understand that there is sound evidence of real structural transformations at the level of social organization caused by the expansion of multinational enterprises and stock markets, the diffusion of popular culture, and the increasing concern with environmental degradation.

Globalists do not portray globalization as an exclusively economic phenomenon. They argue that researchers and analysts should adopt a multidimensional concept that contemplates the diverse networks at the economic, political, environmental, technological and cultural domains (Held \& McGrew, 2000, p.18-20). However they argue that the economic domain, viewed from a 'free market' perspective, has become more important than the others. This explains, from such a standpoint, why reality is becoming increasingly transnational. The relative importance of the national boundary to the understanding and prediction of the so-called global world (which is taken as synonymous to 'global market') is decreasing (Ohmae, 1989a). For this reason, IR academics classify the most IM influential authors as 'hyper-globalists' (Gilpin, 2001). IR academics do not agree with their belief in the erosion of the power of the government to the task of ruling the national economy (see Held et al., 1999, p. 281; Keohane \& Nye, 1998) in a borderless world ruled by non-national 'market' forces.

\section{A Better Approach on Globalization}

A better theoretical approach to globalization has been developed in recent years. Held and McGrew (2000), for instance, challenge both skeptics and globalists. They point out that the debate between these two extremes is problematic for two main reasons. Firstly, because the position held by the skeptics has been transformed into a resource for the legitimization of the position held by the globalists and for its hegemony within the literature. Secondly, because the resulting debate has prevented researchers from recognizing or using a multidimensional theory of globalization.

They argue that the conceptualization of globalization requires the recognition of three fundamental issues: (a) material, (b) time-space and (c) cognitive. The first is represented by the flows of trade, capital and people, which have been facilitated by three types of infrastructure - physical 
(transportation and informatics), normative (international trade rules) and symbolic (English language as the universal language). The second is represented by the change in the spatial reach of social action and organization between the local and global levels. The third is represented by the recognition of the causal relation between remote events, structures and issues and local matters (and vice-versa), as well as corresponding changes in our notions of space and time.

The careful analysis of these issues provides the necessary foundations for the statement that globalization exists. They also point out that globalization does not mean 'universalism'. Accordingly, one should not take as 'natural' or inexorable the harmony between interests of different parts, the universalization of values, or the convergence of cultures and civilizations. Rather, globalization should be taken as a complex socio-historical process that carries with it political features and structures. Globalization, from this perspective, generates dynamic and ambiguous processes of cooperation in addition to those of animosity and conflict.

In a similar way, Thompson (2000, p. 90-91) states that the debate on globalization has been undertaken from three theoretical perspectives: (a) globalist, (b) traditionalist and (c) transformationalists (see Table 2). The author points out the flows of international trade as one piece of evidence of the increasing interdependence of the world economy. He also stresses the flows of capital, especially through foreign direct investments (FDI), as more important evidence. Like Held and McGrew, Thompson does not deny globalization as a real phenomenon.

The author argues that the volume increase of FDI since the early 1980s is one of the most important proofs that globalization exists. Nevertheless, he argues that the relative importance of flows of capital within the Gross Domestic Products of national economies means that the contemporaneous international economy is not as much globalized as it was in 1913. Accordingly, he denies the argument held mainly by globalists that the state and its corresponding political agency stopped making the difference inthe early 1990s (Keohane \& Nye, 1998, made a similar argument).

Thompson argues then that the approach called 'trilateral regionalism' is more suitable for the understanding of the international economic system. More specifically the author argues that the triad - US, Japan and European Union - accounts for more than $75 \%$ of the world economy and that, correspondingly, almost $85 \%$ of the world population has been excluded from the major benefits generated by globalization (Thompson, 2000, p. 110). He also argues that in spite of the free-market discourse spread worldwide by globalists the triad remains closed in terms of interdependence and integration of investments. This means that TNCs should not be uncritically taken as 'transnational' since they remain 'governed' from a political and national standpoint (see also Gilpin, 2001).

Table 2: Theoretical Perspectives on Globalization

\begin{tabular}{|c|c|}
\hline Perspectives & Key Assumptions \\
\hline Globalist & $\begin{array}{l}\text { - There is a fully developed global economy that has supplanted previous forms of } \\
\text { the international economy. } \\
\text { - The global economy is driven by uncontrollable market forces, which have led to } \\
\text { unprecedented cross-national networks of interdependency and integration. } \\
\text { - National borders have dissolved and therefore the category of a national economy is } \\
\text { now redundant. } \\
\text { - All economic agents have to conform to the criteria for being internationally } \\
\text { competitive. } \\
\text { - The position is advocated by economic neo-liberals but condemned by neo- } \\
\text { Marxists }\end{array}$ \\
\hline Traditionalist & $\begin{array}{l}\text { - The international economy has not progressed to the stage of a global economy to } \\
\text { the extent claimed by the globalists. } \\
\text { - Separate national economies remain a salient category. } \\
\text { - It is still possible to organize cooperation between national authorities to challenge } \\
\text { market forces and manage domestic economies and govern the international }\end{array}$ \\
\hline
\end{tabular}




\begin{tabular}{|l|l|}
\hline & $\begin{array}{l}\text { economy. } \\
\text { The preservation of entitlements to welfare benefits, for instance, can still be } \\
\text { secured at the national level. }\end{array}$ \\
\hline Transformationalist & $\begin{array}{l}\text { New forms of intense interdependence and integration are sweeping the } \\
\text { international economic system. }\end{array}$ \\
& $\begin{array}{l}\text { These place added constraints on the conduct of national economic policy making. } \\
\text { They also make the formulation of international public policy to govern and } \\
\text { manage the system very difficult. } \\
\text { This position sees the present era as another step in a long evolutionary process in } \\
\text { which closed local and national economies disintegrate into more mixed, } \\
\text { interdependent and integrated 'cosmopolitan' societies. }\end{array}$ \\
\hline
\end{tabular}

Source: Thompson (2000, p. 90-91).

In short, IR authors challenge the widespread argument, held and spread by globalists, that globalization is based on economic-based competition, free market and collective progress. What is particularly important, given the objectives of this article, is that these authors challenge local governments, especially of less developed countries, that became used to accepting governance rules and mechanisms imposed by TNCs. They argue that the global world is a context of political and complex disputes in which states or governments and TNCs have become key players (Keohane \& Nye, 1998; Strange, 1996; Wallerstein, 2005).

\section{Bringing Governance Issues to IM}

Some other academic areas related to the "international dimension" have been addressing globalization from a more comprehensive perspective. Among those areas (or sub-areas) three deserve our attention: (a) international political economy, with particular focus on the global economy (see Strange, 1994), (b) cultural studies, with particular focus on global culture (see Featherstone, 1990), and (c) global sociology, with particular focus on transnational actors and structures (see Sklair, 1995).

Even though the main authors of these three areas acknowledge that the concept of globalization lacks precision, they agree that one issue should not be neglected by academics and authorities: governance within the global context. A major question for them is: is there any form of 'global' governance? (see also Held, 2000; Hirst \& Thompson, 1998).

Among these three areas the area of International Political Economy (IPE) deserves special attention given the main objectives of this article to develop an interdisciplinary framework to address both management and governance levels in IM research in developing countries. The most important argument of IPE is that researchers should address the political and the economic domains properly. More specifically it is argued that researchers should preserve the analytical properties of each of those domains instead of imposing one on the other.

A key issue in IPE is the recognition of the influence of ideologies and interests in the production and diffusion of academic knowledge. IPE authors challenge the idea that knowledge related to the international dimension can be taken as 'neutral'. This is a very important message to most IM researchers and to the dominant literature. The major focus of IPE critical authors is the complex relations and interactions between the 'authority' - depicted in a simplified fashion as the political domain - and the 'market' - depicted also in a simplified fashion as the economic domain (Strange, 1994, 1996). Some IPE authors place emphasis on the authority (represented by realist and nationalist schools), others to the market (represented by economic and liberal schools), and some others to the possibility of a balanced relation between the authority and the market (represented by idealist and socialist schools).

IPE researchers pay special attention to the increasing power of TNCs in developing countries from a perspective of governance. In this respect it is worth mentioning an extensive investigation, 
grounded on an interdisciplinary approach, which aimed to understand the dynamics between governments and TNCs in Malaysia, Brazil and Kenya. This study pulled down the "Berlin Wall" that has separated the London Business School and the London School of Economics for decades (Strange, 1992) as the authors managed to develop an interdisciplinary approach on IPE and international business (Stopford \& Strange, 1991).

Drawing upon the increasing interdependence between states, between business organizations, and between business organizations and states, Stopford and Strange (1991) argue that national governments in developing countries recognize the importance of 'managing' the scarce resources controlled by TNCs. More specifically, they point out that some structural transformations within the technological, financial and political domains in recent years have forced national governments to cooperate and negotiate with TNCs.

The authors investigated a number of processes of negotiation between governments and companies concerning specific investment projects in those three developing countries. Among the key contributions of this investigation, we point out the triangular diplomacy framework. The most important feature of the framework is that it adds two dimensions to the traditional domain of diplomacy: "government must now bargain not only with other governments, but also with firms or enterprises, while firms now bargain both with governments and with one another" (Strange, 1992, p.1).

Besides the traditional negotiations between states through corresponding governments, the authors pointed out that companies and government negotiate and that companies negotiate among themselves (see Figure 1).

Figure 1: Triangular Diplomacy: An Interdisciplinary Framework

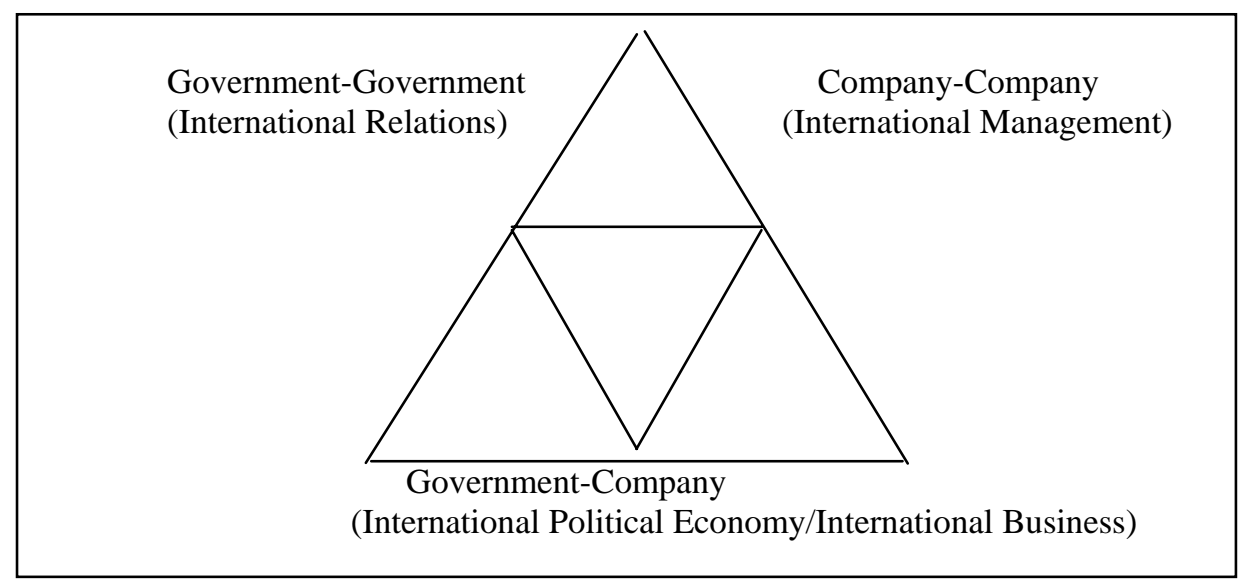

Source: adapted from Stopford and Strange (1991, p. 22).

This interdisciplinary framework shows us that TNCs are as much concerned with governance issues as with management issues, especially in developing countries. Correspondingly, it also shows that IM researchers should challenge the hegemony of the globalist theory within the field and pay special attention to governance matters.

Stopford and Strange state that national governments, especially in developing countries, have lost much of their bargaining power to TNCs since the early 1990s. Although states still control access to their territory and labor, corporations control capital and technology (or have better access to both). Due to the increasing importance of capital and technology in global capitalism, TNCs have increased their bargaining power. In the end, the authors suggest that governments and companies should learn how to 'manage' more effectively these new complexities from the perspective of sustainable growth. 
This triangular diplomacy framework is an important development based on a more comprehensive theory of globalization ${ }^{(8)}$. The framework might lead us to rethink practices, education and research within the IM field in order to make it more representative of the business-government reality, especially in developing countries (Westney, 2005).

The debates on the need formultidisciplinary and interdisciplinary, multilevel, multiple units of analysis and cross-cultural collaborative research in the IM field have been intensified over the last years (Boddewyn et al., 2004; Martínez \& Toyne, 2000). In practical terms, it recommended that IM researchers should foster management inquiry grounded on two paradigms (cross-border and emerging, interaction paradigms) provided by the IB field (see Martínez \& Toyne, 2000), rather then grounded on one or the other.

In short, those arguments set the understanding that neither the economic performance of TNCs nor the political performance of governments can be addressed by frameworks centered at the 'management' level. Accordingly, IM researchers should recognize the interfaces between governance and management. They could problematize not just private actors and organizations but also the public ones; not just the private features of TNCs and the public features of states, but mainly the public and private features of both.

The authors of this article argue that this broad standpoint, which requires interdisciplinary developments, is particularly relevant to developing countries for their local government and local corporations as well as to their managers and administrators. Local government and local corporations, in Latin America and in other developing regions, have to deal not only with power asymmetries in relation to developed countries but also with asymmetries in relation to big TNCs (Mortimore, 2000; Sklair, 2001).

\section{FinAL CONSIDERATIONS AND FUTURE IMPLICATIONS}

This article has attempted to show that IM researchers should address not only management but also governance issues. As a result of the increasing importance of TNCs, this article has shown that IM involves not only managers and their specific needs but also diverse types of organizations, policy makers, managers, consumers, citizens, academics and other social/political actors. A governance standpoint on IM might help researchers and 'international managers' to understand with more accuracy what international management seems to be all about. This standpoint, which is particularly relevant in developing countries, should focus on the political and economic practices of transnational institutions, governmental authorities, top executives and stockholders of TNCs, non-governmental organizations, local institutions and also on networks formed by those actors.

By challenging the hegemony of the globalist theory within the IM field through a multidimensional and interdisciplinary perspective, the more comprehensive approach sketched in this article could make the knowledge produced by the field relevant not only to TNCs but also to local governments, local managers, public administrators and policy makers in developing countries.

The development of such an interdisciplinary framework is based on the argument that the IM literature is not neutral. This article showed that US scholars have been both enabled and constrained, consciously or not, by ideological and material mechanisms that are very much national (and political) in character. This helps account for why the dominant literature does not recognize the governance issues pointed out by IPE. In order to challenge the apparent neutrality and universality of the dominant literature, IM researchers in developing countries might foster interdisciplinary developments with the IR field in general and more specifically with the area of IPE.

In parallel, the debate over the need for multidisciplinary and interdisciplinary, multilevel, multiple units of analysis and cross-cultural collaborative research in IM and IB has become intensified over 
the last few years. Based on the triangular diplomacy framework, we suggest that IM researchers should develop interdisciplinary research with the IR, IPE and also the IB fields. Such a framework could represent better the complexities of the business-government relationships in developing countries in the context of globalization.

This type of interdisciplinary development is not easy to implement as a result of the dominance of the globalist theory within the IM field. In this respect the authors of this article suggest that IM researchers should recognize that TNCs have benefited from the weakening of the state or the government in the era of globalization and that this has generated controversial outcomes (also within the academic setting). For this reason, no matter what the efforts undertaken by individual researchers, the interdisciplinary approach proposed in this article only could be effectively developed in developing countries if it were to receive the support of the main academic institutions and agencies.

The authors of this article argue that the field of IM is too important in the context of globalization to be addressed from a standpoint that overlooks the political, the economic, and the ideological dimensions of knowledge in management or international management (Clark \& Knowles, 2003; Clegg et al., 1999).

\title{
NOTES
}

\begin{abstract}
${ }^{1}$ See Acedo and Casillas (2005) for the main paradigms within the IM field. See also Ricks, D., Toyne, B., \& Martínez, Z. (1990). Recent development in the international management research, Journal of International Management, 16(2), 219-253 for the results of a survey undertaken in 1988 in which business-government relations (following two orientations, i.e., reactive and proactive processes) was pointed out by respondents as one of the eight key areas in international management.

${ }^{2}$ Clark and Knowles (2003) point out the predominance of a pro globalization view and the need for interdisciplinary study in the IB field. See Martínez and Toyne (2000) for a subjective account on the need for interdisciplinary approaches in the IM field. See also Boddewyn (1999) and Contractor (2000) for what differentiates IM from IB.

${ }^{3}$ We agree, for instance, with the argument that while TNCs have always been political, the demands and opportunities of the global economy "require them to be political in a more systematic sense than previously" (Sklair, L. (1998). As political actors. New Political Economy, 3(2), 284-287). Accordingly, the understanding of what 'international management' does or is capable of doing, as well as 'international managers', requires us to address the 'governance system'. There is no single definition of governance. Governance is addressed in this article as "the totality of institutional arrangements - including rules and rule-making agents - that regulate transactions inside and across the boundaries of an economic system" (Hollingsworth et al., 1994, p. 8), in which TNCs and other powerful organizations and institutions are historically embedded. Our perspective is in line with recent debates which claim for a definition of 'international management' that goes beyond the traditional definition of 'management crossing borders'.
\end{abstract}

${ }^{4}$ Kedia (2006, p. 243) points out the political feature of the international dimension in business schools in the US. He reminds us that "the focus on emphasizing international business education was intensified with the passage of the Higher Education Act of 1965 (by section 6261 of the Omnibus Trade and Competitiveness Act of 1988). This act created the Business and International Education (BIE) and the Centers for International Business Education and Research (CIBER) programs for colleges of business in the US.”

${ }^{5}$ Early dependency theory concentrated on the structural constraints faced by the governments of host countries (Cardoso, F. H., \& Faletto, E. (1979). Dependency and development in Latin America. Berkeley, CA: University of California. The state was portrayed as subordinate to international capital, which in turn contributed to the continued underdevelopment of the Third World. A revisionist approach to dependency theory proposed a less unbalanced relationship between MNEs and the host country. The study of Evans, P. (1979). Dependent development. Princeton, N.J.: Princeton University, undertaken in Brazil points out that the host country's economic development was shaped by a 'triple alliance' between MNEs, the state and local capital.

${ }^{6}$ See Mortimore (2000) for an overview of recent corporate strategies of FDI in Latin America, which resulted in huge benefits for TNCs, at the expense of national development goals.

${ }^{7}$ It was first presented in 1990 by John Willamson, an economist from the Institute for International Economics, an international economic think tank based in Washington D.C. It is so called because it attempts to summarize the commonly shared themes among policy advice by Washington-based institutions, such as the International Monetary Fund, World Bank, and U.S. Treasury Department, which were believed to be necessary for the recovery of Latin America from the financial crises of the 1980s. 
${ }^{8}$ Stopford, J. (2005). Revisiting rival states. In R. Grosse (Ed.). International business and government relations in the $21^{\text {st }}$ Century. Cambridge: Cambridge University Press, reports that the "triangular bargaining will continue to explain a good deal of the interactions" in the business-government relationships, but "there are ... additions needed to bring the model up to date" such as (a) the role of both non-governmental organizations and international institutions, (b) the power of individuals to protest and boycott specific investments and, (c) the power of the US in favor of US companies.

\section{REFERENCES}

Acedo, F. J., \& Casillas, J.C. (2005). Current paradigms in the international management field: an author co-citation analysis. International Business Review, 14(2), 619-639.

Arbix, G. (2000). Guerra fiscal e competição intermunicipal por novos investimentos no setor automotivo. Dados - Revista de Ciências Sociais, 43(1), 5-43.

Banerjee, S., \& Linstead, S. (2001). Globalization, multiculturalism and other fictions: colonialism for the new millenium? Organization, 8(4), 683-722.

Bartlett, G., \& Ghoshal, S. (1989). Managing Across Borders. London: Century.

Baruch, Y. (2001). Global or north American? A geographical based comparative analysis of publications in top management journals. International Journal of Cross Cultural Management, 1(1), 109-126.

Boddewyn, J. J. (1999). The domain of international management. Journal of International Management, 5(1), 3-14.

Boddewyn, J., Toyne, B., \& Martínez, Z. (2004). The meanings of “international management”, Management International Review, 44(2), 195-212.

Boje, D. (1999). Is Nike roadrunner or Wile E. coyote? A postmodern organization analysis of double logic. Journal of Business and Entrepreneurship, 8(2), 77-109.

Boje, D. (2000). Spectacles and festivals of organization: managing ahimsa production and consumption. Cresskill, NJ: Hampton.

Boje, D. (2001). Corporate writing in the web of postmodern culture and postindustrial capitalism. Management Communication Quarterly, 14(3), 507-516.

Boyacigiller, N., \& Adler, N. (1991). The parochial dinosaur: organization science in the global context. Academy of Management Review, 16(2), 262-290.

Buckley, P. (Ed.). (2005). What is International Business? London: Palgrave.

Caldas, M., \& Wood, T., Jr. (1997). For the english to see: the importation of managerial technology in late 20th century. Organization, 4(4), 517-534.

Case, P., \& Silvester, K. (2000). Close encounters: ideological invasion and complicity on international management master’s programme. Management Learning, 31(1), 11-23.

Chandler, A. D. (1962). Strategy and Structure. Cambridge: MIT Press.

Chang, S. J., \& Ha, D. (2001). Corporate governance in the twenty-first century: new managerial concepts for supranational corporations. American Business Review, 19(2), 32-44. 
Child, J. (2002). The international crisis of confidence in corporations. Academy of Management Executive, 15(3), 145-147.

Clark, W., \& Demirag, I. (2002). Enron: the failure of corporate governance. Journal of Corporate Citizenship, 2(8), 105-122.

Clark, T., \& Knowles, L. (2003). Global myopia: globalization theory in international business. Journal of International Management, 9(4), 361-372.

Clegg, S., Ibarra-Colado, E., \& Bueno-Rodriguez, L. (Eds.). (1999). Global management - universal theories and local realities. London: Sage.

Contractor, F. J. (2000). The raisons d'être for international management as a field of study. Journal of International Management, 6(1), 3-10.

Czinkota, M., Rivoli, P., \& Ronkainen, I. (1992). International business. (2nd ed.). New York: The Dryden Press.

Dicken, P. (1998). Global shift - transforming the world economy. (3nd ed.). London: Paul Chapman.

Doz, Y. (1986). Government policies and global industries. In M, Porter (Ed.). Competition in global industries. Boston: Harvard Business School.

Dunning, J. (1998). An Overview of Relations with National Governments. New Political Economy, 3(2), 280-284.

Featherstone, M. (Org.). (1990). Cultura global. Petrópolis: Vozes.

Furtado, C. (1999). O capitalismo global. (3rd ed.). São Paulo: Paz e Terra.

Gilpin, R. (2001). Global political economy. Princeton: Princeton University Press.

Halliday, F. (1994). Rethinking international relations. London: MacMillan Press.

Halliday, F. (1999). Repensando as Relações Internacionais. Porto Alegre: Ed. UFRGS e FAPA.

Halliday, F. (2001). The world at 2000. London: Palgrave.

Hampden-Turner, C., \& Trompenaars, F. (1993). The seven cultures of capitalism. New York: Doubleday.

Held, D. (2000). Regulating globalization? The reinvention of politics. International Sociology, 15(2), 394-408.

Held, D., \& McGrew, A. (2000). An introduction to the globalization debate. Cambridge: Polity Press.

Held, D., McGrew, A., Goldblatt, D., \& Perraton, J. (1999). Global transformations - politics, economics and culture. London: Polity Press.

Hettne, B. (1995). Development theory and the three worlds. Harlow: Longman.

Hirst, P., \& Thompson, G. (1998). Globalização em questão. A economia internacional e as possibilidades de governabilidade. Petrópolis: Editora Vozes.

Hofstede, G. (1980). Culture’s consequences. London: Sage. 
Hollingsworth, J., Schimitter, P., \& Streeck, W. (Eds.). (1994). Governing capitalist economies: performance and control of economic sectors. Oxford: Oxford University.

Humphrey, J. (2000). Assembler-supplier relations in the auto-industry: globalization and national development. Competition and Change, 4(3), 245-271.

Jackson, T. (Ed.). (1995). Cross-cultural management. Oxford: Butterworth-Heinemann.

Jackson, R., \& Sorensen, G. (1999). Introduction to international relations. Oxford: Oxford University Press.

Jenkins, R. (1987). Transnational corporations and uneven development. London: Routledge.

Kaikati, J., \& Label, W. (1980). American bribery legislation: an obstacle to international marketing. Journal of Marketing, 44(4), 38-46.

Keohane, R., \& Nye, J. (1977). Power and interdependence: world politics in transition. Boston: Little, Brown.

Keohane, R., \& Nye, J. (1998). Power and interdependence in the information age. Foreign Affairs, 77(5), 81-89.

Kedia, B. L. (2006). Globalization and the future of international management. Journal of International Management, 12(2), 242-245.

Klein, N. (1999). No logo: taking aim at the brand bullies. New York: Picador US.

Klijn, E., \& Koppenjan, J. (2000). Public management and policy networks: foundations of a network approach to governance. Public Management, 2(2), 135-158.

Korten, D. (2001). When corporations rule the world. (2nd ed.). Bloomfield: Kumarian Press.

Krugman, P. (2001). Internacionalismo pop. Rio de Janeiro: Campus.

Larry, G. (1994). Public-private partnership in economic development: a review of theory and practice. Economic Development Review, 12(1), 7-15.

Locke, R. (1996). The collapse of the american management mystique. Oxford: Oxford University.

Martínez, Z., \& Toyne, B. (2000). What is international management, and what is its domain? Journal of International Management, 6(1), 11-28.

Mintzberg, H. (1996). Managing government. Governing management. Harvard Business Review, 74(3), 75-83.

Mir, R., Mir, A., \& Srinivas, N. (2004). Managerial knowledge as property: the role of universities. Organization Management Journal, 1(2), 126-137.

Mokhiber, R., \& Weissman, R. (1999). Corporate predators. Monroe: C. Courage.

Mortimore, M. (2000). Corporate strategies for fdi in the context of latin america's new economic model. World development, 28(9), 1611-1626.

Ohmae, K. (1989a). Managing in a borderless world. Harvard Business Review, 67(3), 152-161. 
Ohmae, K. (1989b). The global logic of strategic alliances. Harvard Business Review, 67(2), 143-154.

Ohmae, K. (1990). The borderless world: power and strategy in the interlinked economy. New York: Free Press.

Parker, B. (1997). Evolução e revolução: da internacionalização à globalização. In S. Clegg, C. Hardy, \& W. Nord (Orgs.). Handbook de estudos organizacionais. São Paulo: Atlas.

Pinzani, A. (2002). Patriotismo e responsabilidade na época de globalização. Civitas, 2(1), 211-228.

Porter, M. (2000). Location, competition, and economic development: local clusters in a global economy. Economic Development Quarterly, 14(1), 15-34.

Rocha, A. (2002). A internacionalização das empresas brasileiras. Rio de Janeiro: Mauad.

Said, E. (1979). Orientalism. New York, NY: Vintage.

Sklair, L. (1995). The sociology of the global system. (2nd ed.). Hemel Hampstead: Harvester Wheatsheaf.

Sklair, L. (2001). The transnational capitalist class. Oxford: Blackwell.

Sklair, L. (2002). Globalization, capitalism \& its alternatives. Oxford: Oxford University Press.

Sorensen, G. (1983). Transnational corporations in peripheral societies: contributions towards selfcentered development? Aalborg: Aalborg University.

Soros, G. (1998). The crisis of global capitalism. London: Little, Brown and Company.

Steffek, J. (2003). The legitimation of international governance: a discourse approach. European Journal of International Relations, 9(2), 249-275.

Stopford, J., \& Strange, S. (1991). Rival states and rival firms: competition for world market shares. Cambridge: Cambridge University Press.

Strange, S. (1992). States, firms and diplomacy. International Affairs, 68(1), 1-15.

Strange, S. (1994). States and markets. (2nd ed.). London: Pinter Publishers.

Strange, S. (1996). The retreat of the state. Cambridge: Cambridge University Press.

Tragtemberg, M. (1980). Administração, poder e ideologia. São Paulo: Moraes.

Thompson, G. (2000). Economic globalization? In D. Held (Ed.). A globalizing world? culture, economics, politics. London, NY: Routledge, The Open University.

Usunier, J-C. (1998). International \& cross-cultural management research. London: Sage.

Wallerstein, I. (1974). The modern world-system. New York: Academic Press.

Wallerstein, I. (2000). Globalization or the age of transition? International Sociology, 15(2), 251-267.

Wallerstein, I. (2005). After developmentalism and globalization, what? Social Forces, 83(3), 12631278.

Weiss, L. (1998). The myth of the powerless state. London: Polity. 
Westney, D. E. (2005). What is international business? A sociologist's view. In P. Buckley (Ed.). What is international business? London: Palgrave. 